\title{
COORDINATION COMPOUNDS OF OXOVANADIUM(IV) BASED ON S-METHYLISOTHIOSEMICARBAZIDE AS DYES FOR THERMOPLASTIC POLYMERS
}

\author{
Maria Cocu*, Stefan Manole \\ Institute of Chemistry of Academy of Sciences of Moldova, 3, Academiei str., Chisinau MD-2028, Republic of Moldova \\ "e-mail:mariacocu@gmail.com
}

\begin{abstract}
The colouring properties of two coordination compounds previously synthesized by us: 8-(1',2'-naphthyl)1-R-3-methyl-6-thiomethyl-4,5,7-triazanona-1,3,5,7-tetraenato-1,1' -diolato(-)-( $\mathrm{O}^{1}, \mathrm{O}^{1}, \mathrm{~N}^{4}, \mathrm{~N}^{7}$-vanadyl, where $\mathrm{R}=\mathrm{CH}_{3}$ (1), $\mathrm{C}_{6} \mathrm{H}_{5}(2)$ have been investigated. These compounds meet the requirements to be used as dyes for thermoplastic polymers. Colouring complexes have a high photostability $\left(7\right.$ points), thermostability $\left(>250{ }^{\circ} \mathrm{C}\right)$ and an intensity of colour, which give a low consumption (0.006 to $0.015 \mathrm{~g}$ medium tone, $0.020-0.100 \mathrm{~g}$ to $100 \mathrm{~g}$ polystyrene intense tone and 0.005 to $0.010 \mathrm{~g}$ medium tone and $0.015-0.035 \mathrm{~g}$ intense tone for $100 \mathrm{~g}$ polyethylene). The investigated compounds stained polystyrene and polyethylene in claret-brick. Compound 2 has a higher thermostability $\left(365^{\circ} \mathrm{C}\right)$ than compound $\mathbf{1}\left(285^{\circ} \mathrm{C}\right)$.
\end{abstract}

Keywords: coordination compounds, oxovanadium(IV), dyes, thermoplastic polymer.

Received: March 2015/Revised final: October 2015/Accepted: October 2015

Introduction

Colour is an integral part of the plastic material and it should not be considered as an afterthought. The colorants that are used in the plastics industries can be both dyes and pigments. Dyes must be very strong, transparent and show good heat stability. In the plastics industry dyes are limited in use; therefore they can only be used for a selected number of resins.

Aromatic azo compounds have found a broad spectrum of applications, such as dyes, pigments, food additives, indicators, radical reaction initiators and therapeutic agents [1]. These compounds are mainly used as dyes for textile fibers, wood, wool, leather, metal foil and plastic, also exhibiting a variety of useful properties for biomedical applications [2].

Recently, considerable effort has been dedicated to the synthesis of azo coordination compounds based on Schiff-base ligands, due to their mixed soft-hard donor character $(\mathrm{O}, \mathrm{N}$ and $\mathrm{S}$ donor sites), versatile coordination behaviour [3] and diverse pharmacological properties [4], optical and thermal properties [5], biological properties [6] and their possibility of being used as dyes [7].

The most widely used metal-complex dyes are derived from azo compounds. Although they deliver a multitude of shades, only a few basic components are necessary to produce metal-complex azo dyes.

The template method, where the central ion guides the assembly of polydentate ligands, has an important role in the synthesis of coordination compounds [8]. A number of complex compounds, primarily of transition metals, involving thiosemicarbazones of different denticity, have been prepared and investigated [9]. The condensation of salicylaldehyde thiosemicarbazone with salicylaldehyde in the presence of 3d- elements has changed the thiosemicarbazide functionalized synthetic possibilities (with a coordinating node $\mathrm{MN}_{2} \mathrm{O}_{2}$ ). Previously, $3 \mathrm{~d}$ - element compounds containing thiosemicarbazide (selenosemicarbazidic) block and anthranilic aldehyde [8, 9], acetylacetone S-alchilizotiosemicarbazone and anthranilic aldehyde [10], acetyl(benzoyl) acetone S-alchilizotiosemicarbazones and 1-hydroxy-2- naphthaldehyde were studied [11]. The use of these blocks lead to the diverse sets of coordinated atoms: $\mathrm{N}_{4}$ [8], $\mathrm{N}_{5}$ [12], $\mathrm{N}_{4} \mathrm{O}$ [9], $\mathrm{N}_{2} \mathrm{O}_{4}$ [13], $\mathrm{N}_{2} \mathrm{O}_{2}$ [14] and $\mathrm{N}_{3} \mathrm{O}$ [15]. The coordination mode of thiosemicarbazidic fragment depends on the geometry of the assembling species and is governed by stereochemical preferences of central ion.

In view of the foregoing discussion and and continuing interest in coordination chemistry, our present work describes the colouring properties of two mononuclear open-chain complexes, containing $\mathrm{N}_{2} \mathrm{O}_{2}$ set of donor atoms, previously obtained by us via condensation of acetyl(benzoyl)acetone S-methylisotiosemicarbazone with 1-hydroxy-2naphthaldehyde on the matrix of oxovanadium $\left(\mathrm{VOSO}_{4} \cdot 3 \mathrm{H}_{2} \mathrm{O}\right)$ : 8-(1',2'-naphthyl)-1-R-3-methyl-6-thiomethyl-4,5,7triazaocta-1,3,5,7-tetraenato-1,1'-diolato(-)- $\mathrm{O}^{1}, \mathrm{O}^{1}$, $, \mathrm{N}^{4}, \mathrm{~N}^{7}$-vanadyl(II) [16], where $\mathrm{R}=\mathrm{CH}_{3} 1, \mathrm{C}_{6} \mathrm{H}_{5} 2$ (Figure 1).

Structures of complexes 1 and $\mathbf{2}$ were characterized by elemental analyses, IR, UV-Vis, ${ }^{1} \mathrm{H}$ and ${ }^{13} \mathrm{C}$ NMR spectroscopies and mass spectrometry. Complexes were obtained as fine dark-brown crystalline powder, insoluble in water, methanol, slightly soluble in chloroform, soluble in dimethylsulfoxide and dimethylformamide [11].

Study of some practical properties of these compounds showed, that they can be used in various fields. The influence of compounds $\mathbf{1}$ and $\mathbf{2}$ on the biosynthesis of pectolytic enzymes by Penicillium viride fungus has been studied, through the variation of their concentration in the nutrient medium. The obtained results indicated that the presence of tested compounds induces the biomass accumulation and increases the enzymatic activity. It was established, that by 
adding the compounds at a concentration of $5 \mathrm{mg} / \mathrm{L}$ to the culture medium, the pectolytic activity increases with $c c a$ $14 \%$, in comparison with the control solution [11].

\section{Results and discussion}

A series of compounds with the above-mentioned formula, which differ only by the metal nature, have been studied as dying agents for plastics [13]. It was established, that the colour tone is greatly influenced by the metal atom and is insignificantly influenced by the nature of radical R: nickel(II) compounds colour polystyrene and polyethylene in claret, cobalt(II) compounds - in green with yellow tint, copper(II) compounds - in deep red with yellow tint [17].

The produced compounds have a high thermostability $\left(>250^{\circ} \mathrm{C}\right)$, photostability ( 7 points), migration luminescence, stability and physical-mechanical processing. Given the mentioned properties and both the diversity and intensity of colour [18], they can be used as plastics dyes.

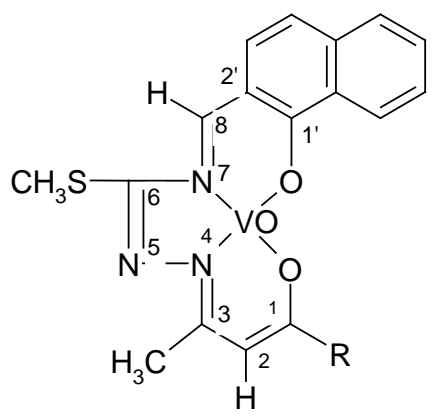

where $\mathrm{R}=\mathrm{CH}_{3}(\mathbf{1}), \mathrm{R}=\mathrm{C}_{6} \mathrm{H}_{5}(2)$

Figure 1. Structure of compounds 1 and 2.

Current article presents the results of our investigations regarding the colouring properties of compounds 1 and 2. These compounds were tested as dyes for colouring polystyrene block, suspension, emulsion and both high and low density polyethylene. The carried out under laboratory conditions experiments are promising for the use of these compounds as dyes for colouring polystyrene and polyethylene.

Coordination compounds $\mathbf{1}$ and $\mathbf{2}$ colour polystyrene and polyethylene in claret-brick. The influence of the radical $\mathrm{R}$ on the colour change of plastic parts is not visually observed, but analysis of the absorption spectra in the visible region suggests an insignificant influence (for complex 1: $\lambda(\mathrm{nm})=334 ; 281$; 242, respectively lg $\varepsilon=4.37 ; 4.50$; 4.26, for complex $2: \lambda(\mathrm{nm})=335 ; 282 ; 244$, respectively $\lg \varepsilon=4.29 ; 4.53 ; 4.33)$.

It should be noted, that one of the advantages of the investigated dyes is their very low consumption for colouring polystyrene (block, emulsion or suspension) and low or high density polyethylene (0.006 to $0.015 \mathrm{~g}$ medium tone, 0.020 to $0.100 \mathrm{~g}$ intense tone to $100 \mathrm{~g}$ polystyrene and $0.005-0.010$ g medium tone, $0.015-0.035 \mathrm{~g}$ intense tone to $100 \mathrm{~g}$ polyethylene), as shown in Table 1.

Table 1

Characteristics of dyes 1 and 2.

\begin{tabular}{|c|c|c|c|c|c|c|c|c|c|c|c|c|c|c|}
\hline \multirow{2}{*}{\multicolumn{2}{|c|}{ Dye }} & \multirow{4}{*}{ 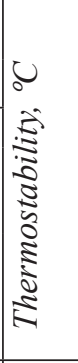 } & \multirow{4}{*}{ 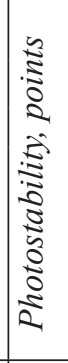 } & \multirow{4}{*}{ 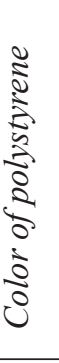 } & \multirow{4}{*}{ 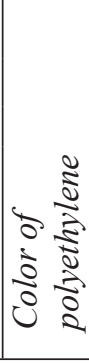 } & \multirow{4}{*}{ 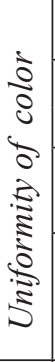 } & \multicolumn{8}{|c|}{ Consumption dyes, g/100 g polymer } \\
\hline & & & & & & & \multicolumn{4}{|c|}{ Polystyrene } & \multicolumn{4}{|c|}{ Polyethylene } \\
\hline \multirow[b]{2}{*}{ No } & \multirow[b]{2}{*}{$R$} & & & & & & \multicolumn{2}{|c|}{ Block type } & \multicolumn{2}{|c|}{$\begin{array}{l}\text { Emulsion, } \\
\text { suspension }\end{array}$} & \multicolumn{2}{|c|}{ High density } & \multicolumn{2}{|c|}{ Low density } \\
\hline & & & & & & & $\begin{array}{l}\text { Middle } \\
\text { tone }\end{array}$ & $\begin{array}{c}\text { Intense } \\
\text { tone }\end{array}$ & $\begin{array}{c}\text { Middle } \\
\text { tone }\end{array}$ & $\begin{array}{c}\text { Intense } \\
\text { tone }\end{array}$ & $\begin{array}{c}\text { Middle } \\
\text { tone }\end{array}$ & $\begin{array}{l}\text { Intense } \\
\text { tone }\end{array}$ & $\begin{array}{c}\text { Middle } \\
\text { tone }\end{array}$ & $\begin{array}{c}\text { Intense } \\
\text { tone }\end{array}$ \\
\hline 1 & & & & \multirow{3}{*}{\multicolumn{2}{|c|}{$\begin{array}{l}\text { Claret - } \\
\text { brick }\end{array}$}} & \multirow{3}{*}{ 音 } & \multirow{3}{*}{$\begin{array}{c}0.006- \\
0.010\end{array}$} & \multirow{3}{*}{$\begin{array}{c}0.050- \\
0.100\end{array}$} & \multirow{3}{*}{$\begin{array}{c}0.010- \\
0.015\end{array}$} & \multirow{3}{*}{$\begin{array}{c}0.020- \\
0.080\end{array}$} & \multirow{3}{*}{$\begin{array}{c}0.005- \\
0.010\end{array}$} & \multirow{3}{*}{$\begin{array}{c}0.015- \\
0.035\end{array}$} & \multirow{3}{*}{$\begin{array}{c}0.008- \\
0.010\end{array}$} & \multirow{3}{*}{$\begin{array}{c}0.015- \\
0.035\end{array}$} \\
\hline & $\mathrm{CH}_{3}$ & 285 & 7 & & & & & & & & & & & \\
\hline 2 & $\mathrm{C}_{6} \mathrm{H}_{5}$ & 365 & 7 & & & & & & & & & & & \\
\hline
\end{tabular}


It should be noted, that changing the concentration of dye, transparent plastic parts with different shades or uniformly coloured non-transparent ones were obtained. Thus, on the basis of their high photostability, the stability towards physico-mechanical processing, the reported complexes may potentially be good choices as dyes for thermoplastic masses. Due to the adhesion of compounds $\mathbf{1}$ and $\mathbf{2}$ to polystyrene, their use as dyes for thermoplastic masses does not require additional agents for grain processing. In this case the dye consumption is reduced significantly.

\section{Conclusion}

Due to their colouring capacities, along with the other useful properties, such as high thermo- and photo stability and very simple and inexpensive methods of synthesis, the proposed complexes can be used as dyes for colouring thermoplastic polymers.

\section{Experimental}

Polystyrene in block, emulsion or granulated suspension is mixed with the dye in a reactor supplied with a thermometer, a stirrer and a tap to release the obtained content from the reactor into the form. The mixture in the reactor is stirred and heated up until components melt; afterwards they are fused in the required form. When colouring polyethylene, a more intense stirring is required, since the adherence of the dye to polyethylene is lower than to polystyrene.

\section{References}

1. You, W.; Zhu, H-Y.; Huang, W.; Hu, B.; Fan, Y.; You, X-Z. The first observation of azohydrazone and cis-trans tautomerisms for disperse yellow dyes and their nickel(II) and copper(II) complexes. Dalton Transaction, 2010, 39, pp. 7876-7880.

2. Kowol, C.R.; Heffeter, P.; Miklos, W.; Gille, L.; Trondl, R.; Cappellacci, L.; Berger, W.; Keppler, B. K. Mechanisms underlying reductant-induced reactive oxygen species formation by anticancer copper(II) compounds. Journal of Biological Inorganic Chemistry, 2012, 17, pp. 409-423.

3. Roy, S; Mandal, T.; Barik, A.; Pal, S; Gupta, S.; Hazra, A.; Ray, J.; Butcher, A.; Hunter, M.; Zeller, S.; Kumar, $\mathrm{K}$. Metal complexes of pyrimidine derived ligands - syntheses, characterization and X-ray crystal structures of $\mathrm{Ni}(\mathrm{II}), \mathrm{Co}(\mathrm{III})$ and Fe(III) complexes of Schiff base ligands derived from S-methyl/S-benzyl dithiocarbazate and 2-S-methylmercapto-6-methylpyrimidine-4-carbaldehyde. Polyhedron, 2007, 26, pp. 2603-2614.

4. Pahontu, E.; Fala, V.; Gulea, A.; Poirier, D.; Tapcov, V.; Rosu, T. Synthesis and characterization of some new $\mathrm{Cu}(\mathrm{II}), \mathrm{Ni}(\mathrm{II})$ and $\mathrm{Zn}(\mathrm{II})$ complexes with salicylidene thiosemicarbazones: antibacterial, antifungal and in vitro antileukemia activity. Molecules, 2013, 18, pp. 8812-8836.

5. Hamid, K.; Maryam, D. Copper (II) Complexes of pyridazine-based azo-azomethine ligands: synthesis, characterization thermal and absorption properties. Journal of Inorganic and Organometallic Polymers, 2011, 21, pp. 541-546.

6. Serda, M.; Mrozek-Wilczkiewicz, A.; Jampilek, J.; Pesko, M.; Kralova, K.; Vejsova, M.; Musiol, R.; Ratuszna, A.; Polanski, J. Investigation of the biological properties of (hetero)aromatic thiosemicarbazones. Molecules, 2012, 17, pp. 13483-13502.

7. Hamid, K.; Khatereh, R.; Mostafa M. A.; Seik,W. N. Azo-azomethine dyes with N, O, S donor set of atoms and their Ni(II) complexes: Synthesis, characterization and spectral properties. Dyes and Pigments, 2013, 98, pp. 557-564.

8. Garbalau, N.; Arion, V. Template synthesis of macrocyclic compound. Stiinta: Chisinau, 1990, 374 p. (in Russian).

9. Gerbeleu, N.; Arion, V.; Burges, J. Template synthesis of macrocyclic compound. Wiley-VCH: Weinheim, 1999, $565 \mathrm{p}$.

10. Gradinaru,J.;ForniA.; Druta, V.Ni(II)complexeswith[ $\left.\mathrm{N}_{3} \mathrm{O}\right]$ Schiffbaseligandsbearing S-methylisothiosemicarbazide unit: design, synthesis and structure. Inorganica Chimica Acta, 2002, 338, pp. 169-181.

11. Cocu, M.; Gradinaru, J.; Revenco, M.; Rybak-Akimova, E.; Garbalau. N. Template synthesis and investigation of some 3d-elements coordination compounds with tetradentate ligands derived from alkylated thiosemicarbazide. Chemistry Journal of Moldova, 2008, 3(2), pp. 38-47.

12. Leovac, V.; Bogdanovic, G.; Ceslijevic, V. and Divjakovic, V. Transition metal complexes with thiosemicarbazidebased ligands. XV. A square-pyramidal $\mathrm{Ni}^{\mathrm{II}}$ complex with an asymmetric coordination of 2,6-diacetylpyridine bis $(S$ methylisothiosemicarbazone). Acta Crystallografica. Section C, 2000, 56, pp. 936-938.

13. Garbalau, N.; Jovmir, T. Template synthesis and properties of nickel coordination compounds with binuclear ligands based on thiosemicarbazide and 3-formylsalycilic acid. Journal of Inorganic Chemistry, 1984, 29(9), pp. 2304-2308 (in Russian).

14. Gradinaru, J.; Forni, A.; Simonov, Yu.; Popovici, M.; Zecchin, S.; Gdaniec, M.; Fenton, D. Mononuclear nickel(II) and copper(II) complexes with Schiff base ligands derived from 2,6-diformyl-4-methylphenol and S-methylisothiosemicarbazones. Inorganica Chimica Acta, 2004, 357, pp. 2728-2736. 
15. Forni, A.; Gradinaru, J.; Druta, V.; Zecchin, S.; Quici, S.; Gerbeleu N. Cu(II) complexes with asymmetrical [ $\left.\mathrm{N}_{3} \mathrm{O}\right]$ Schiff-base ligands derived from $S$-methylisothiosemicarbazide. Inorganica Chimica Acta, 2003, 353, p. 336-343.

16. Cocu, M. Template synthesis and investigation of some 3d-elements coordination compounds with tetradentate ligands derived from alkylated thiosemicarbazide. Ph.D. Thesis, Institute of Chemistry of ASM. Chisinau, Republic of Moldova, 2007 (in Romanian).

17. Manole, S.; Cocu, M. Coordination compounds of nickel(II), copper(II) and cobalt(II) based on s-methylisothiosemicarbazide as dyes for thermoplastic polymers. Chemistry Journal of Moldova, 2011, 6(2), pp. 70-72.

18. Bastian, M. Coloration of plastics. Profession: St. Petersburg, 2011, 107 p. (in Russian). 